\title{
Beliefs about Student Achievement Held by Teachers at Dutch Universities of Applied Sciences
}

\author{
Abdel Hafid Ballafkih ${ }^{1} \&$ Daniel Van Middelkoop ${ }^{1}$ \\ 1 Amsterdam University of Applied Sciences Centre for Applied Research on Economics \& Management, \\ Wibautstraat 3b 1091 GH Amsterdam, The Netherlands \\ Correspondence: Abdel Hafid Ballafkih, Amsterdam University of Applied Sciences Centre for Applied Research on \\ Economics \& Management, Wibautstraat 3b 1091 GH Amsterdam, The Netherlands. E-mail: A.H.Ballafkih@hva.nl
}

Received: May 10, 2019

doi:10.5430/ijhe.v8n5p45
Accepted: July 31, 2019

Online Published: August 19, 2019

\begin{abstract}
Student achievement is a frequently debated issue in many European countries. In most public debates, it is assumed that all school-level stakeholders hold the same beliefs about student achievement. This paper contributes to the debate by presenting the results of research on the beliefs of teachers regarding student achievement.

The results reveal four beliefs about student achievement held by teachers. The beliefs are centred on student efficiency, learning and enhancing skills, personal development, and active citizenship. The dominant belief is about the preparation for a profession in which a high-achieving student has good prospects of becoming a successful professional in a particular field. The results also show that the dominant belief held by school administrators (management), namely that student achievement is the same as student efficiency (how quickly students complete their studies), is questioned by teachers.
\end{abstract}

Keywords: student achievement, beliefs, teachers' beliefs, beliefs about student achievement, student efficiency

\section{Introduction}

In recent decades, education and student achievement have become important issues in political debates. Student achievement has received much attention partly due to the current focus on fostering a knowledge-based economy and reducing dropout rates in order to reduce governmental expenditures.

Reviews of educational research (e.g. Hattie, 2008; Marzano, 2003) have shown that several stakeholders have different interests in education as well as different beliefs regarding the aim of education (e.g. Fives \& Gill, 2014; Norton, Richardson, Hartley, Newstead \& Mayes, 2005). Research indicates that school-level stakeholders, such as school management, teachers and students, influence student achievement (e.g. Marzano, Waters, McNulty \& more, 2005; Marzano, 2003). Other studies have found that governmental policies on education influence achievement (Hanushek \& Raymond, 2004; Hattie, 2013) not only through system or regulation-related changes but also by holding the school management accountable for students' achievement (e.g. Dinham, 2005; Harris, 2005).

Numerous studies have focused on the indicators that influence student achievement. Many of these studies have attributed a substantial part of student achievement to teacher effectiveness (e.g. Darling-Hammond, 1999; Sanders, Wright \& Horn, 1997). Factors such as the academic ability of teachers, years of teaching experience, teaching knowledge, certification and teaching behaviours have frequently been studied and debated (see, e.g. Ashton \& Webb, 1986; Brophy, 1986; Wayne \& Youngs, 2003).

Although a substantial part of student achievement is attributable to teacher effectiveness, to our knowledge little is known about teachers' beliefs regarding what student achievement actually is. Student achievement is the goal of nearly every aspect of education and as a result it is a concept that is difficult to define (Guskey, 2013). In international research, the debate on student achievement centres mainly on measurability (e.g. Bos \& Schwippert, 2003). That debate shows that student achievement is susceptible to differences in conceptualisation, measurement and interpretation. Due to these differences, the conceptualisation and use of 'student achievement' has been questioned (e.g. Bos \& Schwippert, 2003) both within and outside the educational arena.

This questioning hints at the existence of different beliefs regarding student achievement among the various school-level stakeholders (Norton et al., 2005). Given the effect of teachers on student achievement, it is important to 
understand the beliefs held by teachers (Nespor, 1987). Drawing on research conducted in the Netherlands, this paper therefore identifies teachers' beliefs regarding student achievement that are likely to affect student achievement policies and debates within educational institutions.

\section{Theoretical Framework}

To understand the beliefs teachers have regarding student achievement, we first briefly outline how student achievement is defined in the literature. We then focus more specifically on how beliefs affect student achievement and how teacher-level factors affect the beliefs teachers have regarding student achievement.

\subsection{Student Achievement}

There are major policy debates in many countries about the nature of education and about student achievement. Student achievement has been one of the most important evaluation criterion used by schools at every level for as long as schools have existed (see e.g. Hattie \& Anderman, 2013). The importance of student achievement seems to have increased in recent decades as the number of students enrolling in higher education has increased significantly (Altbach, Reisberg \& Rumbley, 2009). However, many of the students (30 per cent, OECD average) (Mantz \& Bernard, 2004) who enter the higher education system leave without a degree. Because of the atmosphere of accountability for the costs of student attrition (Hursh, 2005) and the contribution they aim to make to the knowledge economy, many higher education institutions have taken initiatives to decrease student attrition by maximising student achievement. These initiatives and the previously mentioned debates tend to show a special interest in arrangements that are mainly focused on maximising student achievement (Bradshaw, 2013).

Although research identifies numerous factors that affect student achievement (Hattie, 2013; Marzano, 2003; Walberg \& Paik, 2000), the concept itself is treated as 'fixed' and clearly defined (but see Yorke, 2007) even though there is no shared understanding of what it is (Guskey, 2013). Guskey (2013) argued that different stakeholders at the school level might assume that they all mean the same thing when they speak of student achievement, even though this is often not the case; in fact, tremendous variation exists in the stakeholders' definitions. To determine and improve student achievement, a consensus at the school level is needed regarding, at the very least, the definition of student achievement (Guskey, 2007, 2013).

Preparing students by primarily enhancing their hard skills, such as their cognitive skills, is one of the first things that come to mind when student achievement is discussed. According to Guskey (2013), student achievement generally refers to articulated learning goals. The learning goals involve different kinds of learning, subject areas and domains of learning, which reflects that student achievement is a multifaceted construct that is dictated by the tasks (the purposes) of education.

In the literature on the measurement of achievement and the factors that affect student achievement (see e.g. Hattie \& Anderman, 2013), student achievement is defined either broadly or narrowly. When defined narrowly, student achievement is related to 'hard' skills and knowledge that are measured through standardised tests; this is also referred to as academic achievement (Haines \& Mueller, 2013). According to this definition, student achievement is related to the student's ability to reproduce knowledge and tasks. Most research on student achievement adopts this narrow definition and therefore uses grades as a standardised measurement of student achievement. In the context of higher education, this narrow definition enables student achievement to be measured using traditional means such as scores on standardised college entry exams, college grades and credit hours earned in consecutive terms, which represent progress toward a degree (Kuh, Kinzie, Buckley, Bridges \& Hayek, 2006, p. 5). In this approach, student achievement is determined by looking at quantitative indicators (i.e. grades and dropout rates) that proxy the ability (skills and knowledge) of a student and the efficiency of the educational institution. These measurements are used to assess whether students have acquired the skills and knowledge by summarising student performance in a grade (Greaney \& Kellaghan, 2008). This quantitative approach is used to communicate the level of mastery a student has demonstrated in a subject (e.g. Nitko \& Brookhart, 2010), and thus how high the student's achievement is.

This quantitative approach has been criticised by several researchers (e.g. Kuh et al., 2006; Yorke, 2007). Yorke (2007), for example, argued that grades do not sufficiently measure achievement because they can be stable while achievement is not. There is great variability in quantitative measures of achievement. These measures have several validity issues and therefore their use is somewhat limited as a proxy for achievement or institutional efficiency (Yorke, 2007).

In contrast to the narrow definition, the broad definition of student achievement also includes 'soft' skills and personal growth, as well as such qualitative aspects as student engagement in educationally purposeful activities, student satisfaction, student acquisition of desired knowledge, persistence, attainment of educational objectives and 
post-educational performance (see e.g. Kuh et al., 2006). According to this broad definition, student achievement is also related to family, family-school relations, parental involvement in education (see e.g. Seginer, 2006), behaviour and health (Henderson \& Mapp, 2002), performance on the labour market and citizenship. These soft aspects of student achievement are not always measurable by standardised tests.

As mentioned, student achievement is a multifaceted construct that is mainly dictated by the tasks of education. In contemporary western societies, four tasks are attributed to education (Biesta, 2014; Van de Werfhorst, 2014). The first is preparing students for the labour market by teaching them and enhancing their skills that will contribute to the productivity of employers. The second task is to sort students according to their interests and learning abilities. The third task is to provide all members of society with equal access in order to decrease social and economic inequality. The fourth task is to prepare students to become active citizens. The tasks reveal the learning domains and therefore indicate what student achievement entails. The tasks also affect the curriculum (e.g. Biesta, 2014) through the choices that are made regarding the learning domains (see e.g. Hattie \& Anderman, 2013). The tasks of education and the beliefs teachers have about student achievement have a mutual relation.

\subsection{Beliefs Regarding Student Achievement}

There is a tremendous body of research on beliefs (see e.g. Fives \& Gill, 2014) at the collective and the individual level. This research contains a profusion of terms related to teachers' beliefs. It also shows that teachers' beliefs about teaching and learning influence their behaviour in the classroom (e.g. Buehl \& Beck, 2014; Fives, Lacatena \& Gerard, 2014; He \& Levin, 2008; Nespor, 1987; Staub \& Stern, 2002), which consequently affects students' learning and therefore students' achievement. We therefore argue that teachers' beliefs regarding student achievement affect students' achievement through teacher-level factors.

In the literature, beliefs are mainly defined as mental representations formed by knowledge (information, experience, etc.) and knowing (mental state, IQ, etc.). Beliefs are considered subjective claims that a teacher accepts as true (Nespor, 1987). Teachers use beliefs to filter and interpret information, frame problems and tasks, and guide their actions (Buehl \& Beck, 2014).

Individual beliefs are formed via a dynamic interaction between the inner human resources and the outward perspective. The inner human resources include knowledge, insights, intuition and perceptions that are based on a person's beliefs. The outward perspective entails the educational goals, ideals and policies that interact with the inner human resources to result in a belief.

Thompson (1984) described teachers' beliefs as "manifestations of unconsciously held views of expressions of verbal commitments to abstract ideas that may be thought of as part of a general ideology of teaching" (p. 112). Teachers at the school level have or share some kind of teaching ideology that can be referred to as a collective belief. The individual beliefs of teachers form and affect the collective belief, and vice versa. Collective beliefs are similar beliefs about a certain subject (Durkheim, 2014). Durkheim (2014) argued that a collective belief has a 'coercive power' that forces individual beliefs through shared knowledge.

In the context of education, a belief is generally presented as a source of inspiration that guides teachers in the classroom and influences the informal curriculum (Albion \& Ertmer, 2002; Handal \& Herrington, 2003). Research indicates that teachers' pedagogical beliefs, amongst other beliefs, affect their judgments as well as their roles and behaviour in the classroom (see e.g. Ashton \& Webb, 1986; Pajares, 1992). Pajares (1992) argued that "all teachers hold beliefs ... about their work, their students, their subject matter, and their roles and responsibilities ..." (p. 314). Beliefs consist of images of what teachers hope could or might be in their classrooms, their schools, their community and, in some cases, even society as a whole. The beliefs are images of ideal situations that guide teachers' instructional decision-making (Hammerness \& Shulman, 2006; Scales, 2013). A belief brings together teachers' passions, understanding and knowledge about how and what students should be learning and consequently what achievement should entail.

The relation between the beliefs of teachers and their classroom practices is complex. Some scholars argue that teachers' beliefs influence instructional behaviour, whereas others state that the opposite is true or argue in favour of a dialectical reciprocal causation (see e.g. Pajares, 1992). Although the relation is complex, there are reasons to believe that teachers' beliefs regarding student achievement affect their students' achievement through the teachers' role, their attitudes about education, and also through their opinions on matters that are not specifically related to education (Fives \& Gill, 2014; Pajares, 1992).

Brophy (1986) demonstrated that teaching behaviour significantly affects student achievement. Others have indicated that student achievement improves when teachers have particular characteristics and beliefs (see e.g. Albion \& 
Ertmer, 2002; Handal \& Herrington, 2003; Wayne \& Youngs, 2003; Muijs \& Reynolds, 2002; Norton et al., 2005). Several scholars have argued that teachers' beliefs affect the ways in which students learn (see e.g. Hammerness, 1999; Muijs \& Reynolds, 2002), which indicates that teachers' beliefs affect student achievement through teacher-level factors, as argued by Marzano (2003). A teacher's beliefs about student achievement are reflected in the teacher's didactic approach (the way the teacher transfers knowledge, trains students and enhances their skills), educational practices (the relationship between the teacher and student and etiquette inside and outside the classroom) and classroom management (the way in which the teacher implements the curriculum in the classroom) (Marzano, 2003).

Considering the dialectical reciprocal causation between teacher-level factors and beliefs (see e.g. Pajares, 1992), it is likely that the educational tasks affect the beliefs teachers have regarding student achievement, and vice versa. Teachers reshape their beliefs based on their own inner and outer human aspects. This process of reshaping does not always result in one clear belief about a subject. Beliefs are prioritised and involve ideals of alternative arrangements of reality that can contradict each other (Nespor, 1987). Therefore a teacher can have several beliefs regarding student achievement and may define such achievement both narrowly and or broadly.

\section{Methodology}

\subsection{Data Collection}

The data used in this paper are derived from a study on diversity and student achievement at Dutch universities of applied sciences. From December 2010 to September 2012, 25 teacher teams (one of which included teachers with staff responsibilities) at two institutions in Amsterdam and Rotterdam were followed intensively. On average, the teams comprised 11 ( $\mathrm{SD}=1.39$ ) members. We had no influence on team composition with regard to age, sex or social and professional status, and we conducted the research with existing and operational teams. Two of the teams were actively recruited; the other teams participated because their team managers thought it a good idea and/or because the teachers wanted to discuss diversity in relation to student achievement. As shown in Table 1, several teams from different faculties and disciplines participated.

Table 1. Participating faculties and disciplines

\begin{tabular}{lccc}
\hline Faculties & Disciplines & & Teams \\
Management/Business administration & 2 & & 4 \\
Social & & & 7 \\
Economics & 4 & & 5 \\
Health & 2 & & 4 \\
Engineering & 3 & & 4 \\
Staff* & 1 & \\
Total & 16 & & 25 \\
\hline
\end{tabular}

* Staff members with teaching tasks not associated with one faculty

Two meetings were held with the teacher teams. Before the first meeting with each team, a questionnaire with open and closed questions about achievement and diversity was distributed to all the participating teachers. The questionnaire results were used as a starting point for the meetings. In addition to the input from the questionnaire, key documents about student achievement and diversity were studied in the preparation phase of the research, and interviews were held with team managers about the characteristics of the team and the degree of cooperation within it.

The aim of the research was to explore student diversity and achievement in a focus group setting. Because one objective was to capture the beliefs of teachers about student achievement, we aimed for a collective view. According to Morgan (1997), a focus group setting is useful when a collective view is desired. During the team meetings, the teachers were encouraged to speak 'in their own voices', to share their beliefs about student achievement and to discuss these beliefs with their team members to generate a collective view of student achievement.

To optimise the quality of the discussion and the data, a follow-up meeting was planned for each team after approximately nine months, as by then the participants would have absorbed the discussion. Unfortunately, only 14 of the 25 teams were able to participate in a second round of meetings. 
The meetings were held in classrooms at the teachers' institutions. All meetings started with an introduction to the subject. After the introduction, the researchers asked, "What is student achievement according to your beliefs?" After the first question, the researchers' led the teachers in a discussion about their beliefs. During the discussion the researchers' kept the focus by rephrasing the first question, in order to focus on beliefs in the context of student achievements. The researchers intervened in the teachers' discussion by seeking clarification and relating the different beliefs.

Two researchers per team participated in the team meetings. One researcher served as moderator (leading the process, suggesting subjects and asking for clarification and responses), the other as an observer (taking notes). The moderators were instructed to minimise their participation concerning the content. Each meeting was audiotaped and transcribed. All the sources (questionnaire, pre-interviews, team meetings and the key documents on student achievement) were compiled in a report that was provided to the teams for verification.

The data collection is summary visualized in Figure 1.

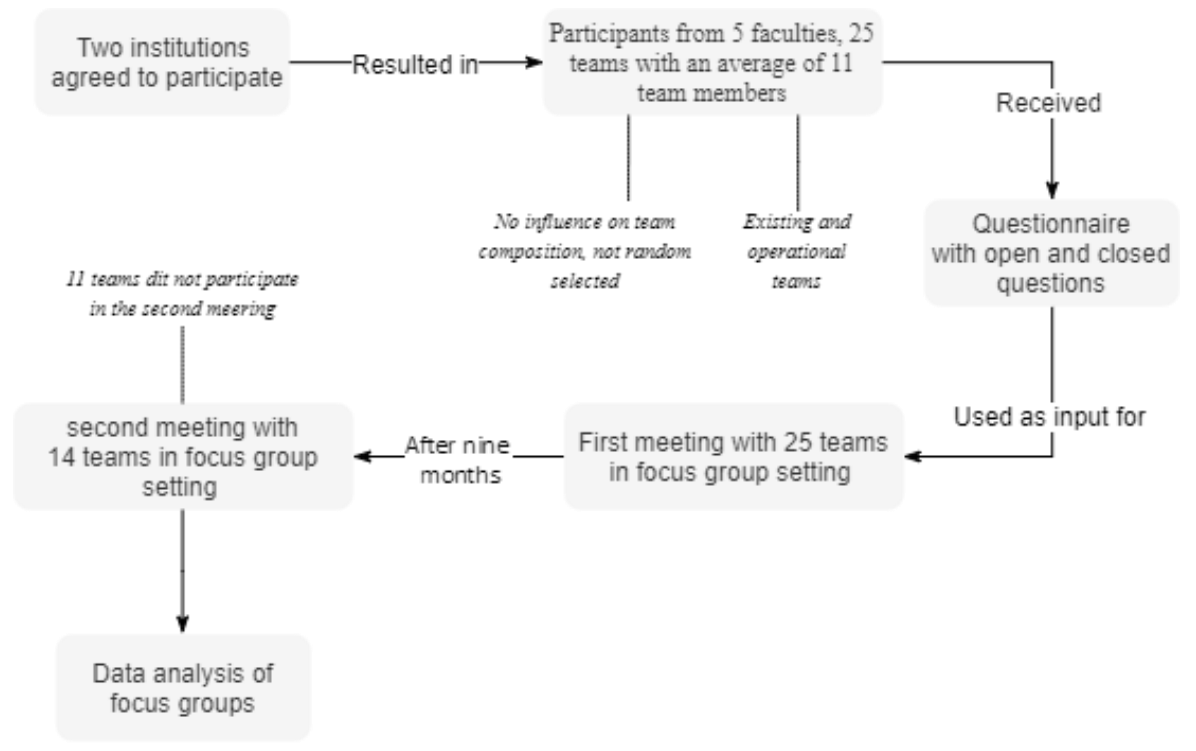

Figure 1. summary the data collection

\subsection{Data Analysis}

Because the aim of the research was to identify the beliefs of teachers, the transcripts were coded in the style of a grounded theory approach. As reliability is more difficult to establish in qualitative than in quantitative research (Campbell, Quincy, Osserman \& Pedersen, 2013; Popping, 2010), we maximised reliability (stability, accuracy and reproducibility) in this research by following the guidelines of Krippendorff (2012).

We maximised reproducibility across researchers by using three researchers. The researcher who did not participate in the team meetings coded and analysed the transcripts. After analysing and coding, the researcher reanalysed the transcripts. A second researcher, who participated in approximately 80 per cent of the team meetings, analysed the transcripts. Differences in findings and interpretations were discussed, and adjustments were made once a consensus was reached. In the case of disagreement, the findings were omitted. The third researcher, who participated in 17 per cent of the team meetings, reanalysed the final findings.

The categories used in this study were generated from the questionnaire, pre-interviews and the transcripts of the team meetings. As described in studies on grounded theory (e.g. Charmaz, 2014), the categories 'emerged' from the data. The following steps were taken to analyse the data: 1) reading the data sources, 2) a round of extensive reading, 3 ) reading extensively and making notes, 4) reading extensively and re-evaluating the notes, 5) labelling the notes, and 6) after labelling, the notes were clustered based on the grounded theory approach with concepts from the literature.

\section{Results}

Before presenting the beliefs that teachers have regarding student achievement, we first briefly provide some insight into the struggle teachers have with the concept of student achievement. 
The teachers were initially reluctant to speak only about student achievement. The teachers mainly wanted to speak about quality of education. Emphasising student achievement in their opinion masks the debate on the quality of education. They therefore tended to emphasise the quality of education when speaking about student achievement, framing the achievement debate within the quality of education debate.

This emphasis on the quality of education seemed to be driven by the teachers' scepticism about how achievement is used within the institutions. The teachers argued that the dominant discourse is primarily about student efficiency, risk reduction and measurability. The call for greater efficiency in several school-level documents fed their scepticism. The focus on efficiency undermines the quality of education, according to the teachers.

The teachers argued that student achievement is described in several school-level documents. The discourse in those documents and within the institutions is mainly about students' efficiency. The teachers' argued that student achievement in those documents is crudely measured by students grades and whether student graduate within time. Student achievement is conceptualised as a student's ability to meet the minimum requirements to pass a course.

The teachers did not consider student achievement and quality of education to be mutually exclusive; rather, they considered them to be integrated concepts that should be incorporated the definition on student achievement.

\section{The teachers' beliefs}

Although the teachers preferred to talk about quality rather than achievement, we asked them to reflect on their beliefs regarding student achievement. The beliefs the teachers have about student achievement centre on four main aspects of achievement: student efficiency; learning and enhancing skills; personal development; and active citizenship

As mentioned, the aspect of achievement that can be described as student efficiency dominated the discussions on student achievement despite the teachers' beliefs that this emphasis is detrimental to efforts to improve the quality of education. This 'efficiency belief' is dominant and shows similarities with the 'belief' portrayed in the documents of the institutions. However, this belief is not preferred, as argued. This emphasis shows a focus on the throughput phase, in which efficiency plays an important role. The teachers believe that education serves to raise students' skills and knowledge to a level that will allow students to pass the tests. Student efficiency can be summarised as the students' ability to reproduce the skills and knowledge they are taught during a course in order to pass tests the first time. As argued, teachers believe that high achievement entails students moving smoothly through their studies, graduating on time, and not dropping out.

The second main aspect of achievement mentioned by teachers involves the learning and enhancing of the skills students need to become professionals in a particular field. This 'learning and enhancing skills' belief was the most supported belief about student achievement. Teachers who discussed this aspect of student achievement emphasised that preparation for the labour market is one of the most important aspects of teaching at universities of applied sciences. These teachers conceptualised student achievement as the extent to which the students' enhanced skills, knowledge and traits contributed to their success in a particular profession.

Therefore, the teachers believe that student achievement is a measurement of how well students will practise the profession on the labour market. This belief is related to the school and the labour market setting, and thus involves school and labour market indicators. However, according to this belief, achievement is realised when students are capable of using their acquired skills, knowledge and traits on the labour market. This belief is closely related to the educational task of preparing students for the labour market: student achievement is delivering professionals to the labour market.

Teachers who hold this belief prefer to deliver students who meet the basic requirements of a certain profession, and to avoid delivering students who do not meet the requirements. The teachers perceive themselves as responsible for the profession and act as gatekeepers of the profession. However, teachers within the same profession and team disagreed on how the labour market should influence what students learn (skills, knowledge and traits) and on whether students should be trained for the current profession or the future profession. The teachers also disagreed on whether an assessment of student achievement should look at whether students possess specific traits related to a particular profession. Most teachers stated that students gain and develop traits that belong to their profession in the field during work placement.

Teachers have conflicting beliefs regarding what junior professionals should be able to do, what a good professional is and how to become a good professional. Some teachers argued that courses should not only train students in the skills and traits required for a particular profession (or demanded by employers), but also teach a broader set of skills and traits that serve similar professions. 
The third belief that emerged concerns the personal development of students. Some of the teachers said that they believe that an important aspect of student achievement is the students' personal growth and learning ability. They argued that teachers should assist students in enhancing their personal growth and learning ability by improving the students' self-awareness and self-reflection. These teachers claimed that greater self-awareness gives students an opportunity to discover more about themselves, the professions for which they are being trained and their future roles as a professionals. Student achievement, according to this belief, entails students having insight into their own strengths and weaknesses when considering themselves as future professionals.

Teachers who share this belief argued that students can only be successful if they learn the skills associated with their professions through self-reflection on their personal and professional conduct and development. Students' ability to learn is linked to their ability to use self-reflection to learn the tasks and traits that are required for the profession and to contribute to the fulfilment of the students' interests. Teachers who share this belief related student achievement to fulfilling the interest of the students based on their learning abilities. They seemed to fit the profession to the students rather than the traditional way of fitting the students to the profession.

A small number of teachers said that they believe that an important aspect of student achievement is the acquisition of the skills and traits students need to become more self-confident when dealing with social and work-related problems. They argued that student achievement is affected by the problems and challenges students face in everyday life. The teachers also argued that the skills and traits that are needed to solve these problems and challenges are also needed to be successful on the labour market and in society. According to their belief, student achievement is related to an individual's personal growth, as well as the acquisition of the skills and traits needed to solve both work-related and non-work-related problems. This personal development belief is therefore closely related to the educational task of delivering professionals to the labour market and, to a lesser extent, preparing students to become active, successful citizens.

The fourth belief that emerged is that student achievement entails that students become active citizens; that is, education should prepare students for active citizenship. This belief, unlike the other beliefs, was mentioned by only a few of the teachers. For the teachers who hold this belief, becoming a professional is not the most important aspect of student achievement. Instead, they believe that students should be equipped with the skills, traits and knowledge needed to become active citizens. In general, these teachers emphasised a discerning mind and a scholarly attitude as important skills. They aspire to teach students how to challenge the way events are occurring and to affect existing systems and structures to improve their own lives and their communities.

Teachers who hold this belief argued that students should learn what it means to live in a democracy, how to understand and internalise their own positions, and how to be scrupulous individuals. Thus, these teachers believe it is their responsibility to prepare students to achieve their goals and contribute to society.

Figure $1 \mathrm{~A}$ and $1 \mathrm{~B}$ show the beliefs and their dominance in the current situation and desired situation. The most significant differences are the differences between student efficiency and learning and enhancing skills. In the current situation the overlap between the beliefs is marginal with respect to desired situation.

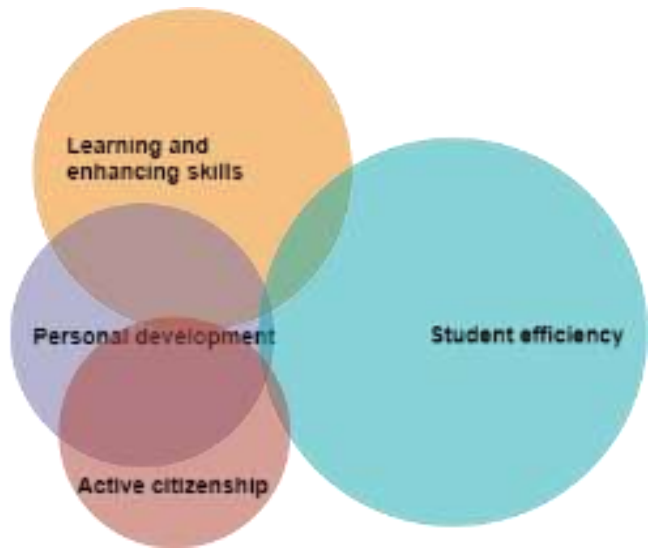

Figure 2.A Beliefs and their dominance (Current situation)

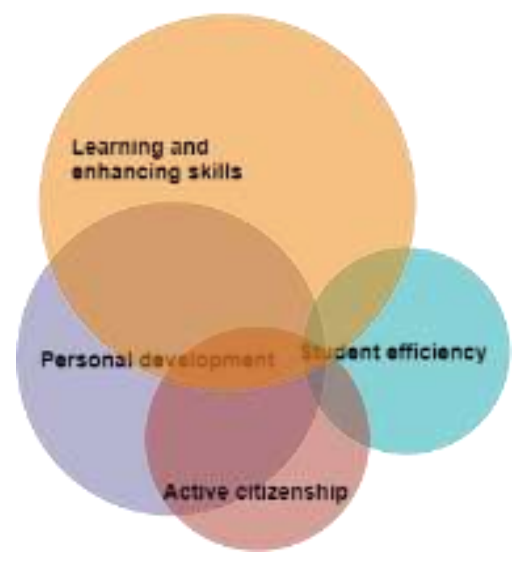

Figure 2.B Beliefs and preferred dominance (Desired situation) 


\section{Conclusion}

The results show that although teachers hold different beliefs about student achievement, one belief is dominant. The beliefs that emerged involve the following four aspects of achievement: student efficiency, preparation for a profession in a particular field, personal development, and preparation to become active citizens. These aspects bear similarities with the tasks of education described in the literature. The teachers seemed to have the domains school, labour market and society in mind when speaking about student achievement. In the school domain, the beliefs refer to achievement at student, course and institution levels. The different levels can be attributed to the various goals and roles of actors (Marzano et al., 2005) and trend for measuring actions and policies (Biesta, 2010).

The dominant belief held by teachers is that student achievement entails preparation for a profession and performance on the labour market. This belief is related to the tasks universities of applied sciences have, namely equipping students with general skills and work attitudes that will enable them to develop new skills on the labour market (see e.g. Biesta, 2010).

The teachers' beliefs indicate that student achievement should also include performance on the labour market. The teachers clearly believe that student achievement involves more than completing studies efficiently. The current focus on efficiency reflects the use of a narrow definition in which grading's are aggregated to efficiency statistics, most likely for measurability reasons and cost accountability (see e.g. Allen, 2005). This narrow definition of student achievement worries the teachers. They are concerned that an overemphasis on efficiency (quantity) is detrimental to delivering well-trained professionals (quality) for the labour market.

This tension indicates a mismatch between teachers' beliefs and the current dominant discourse within their institutions. It is unlikely that the teachers' beliefs about student achievement correspond with those of other institutional stakeholders who are responsible for institutional-level policies. Research on effective leadership in education (e.g. Leithwood, Seashore Louis, Anderson \& Wahlstrom, 2004) has shown that student achievement improves when stakeholders, especially teachers and school management, share the same beliefs about student achievement (Ross \& Gray, 2006). It is therefore important that beliefs are shared by the management and teachers.

Given the findings and the recent public debate in the Netherlands and in other European countries, it can be argued that the different beliefs of teachers should be incorporated into institution-level policies aimed at student achievement. Adopting a broader definition that better fits the beliefs could help to improve student achievement. A definition that includes qualitative and quantitative aspects related to the domains of labour market preparation, performance and personal development is desirable. A better distinction between student achievement definitions related to student, course and school levels are needed to structure the debates on students' achievement.

\section{Limitations and Directions for Future Research}

As Pajares (1992) noted, belief is a messy construct. The beliefs presented in this study are not clear-cut. During the team meetings, the teachers' beliefs oscillated between what is and what should be. The presented beliefs contain several other beliefs, such as beliefs about teaching and beliefs about the role of the teacher and the student (see also Fives \& Gill, 2014). It is likely that these beliefs have an effect on the belief about student achievement. Disentangling the different beliefs is important in order to understand the beliefs that teachers have about student achievement. More in-depth research on their beliefs could improve our understanding of the beliefs and their relations.

A study that compares the beliefs of students, managers and government officials could contribute to our understanding of student achievement. Furthermore, previous research (e.g. Hammerness \& Shulman, 2006) indicated that teachers' beliefs are influenced by several factors, such as their age, years of experience, profession and educational fields. Interviewing teachers and controlling for several variables would likely improve the findings of this study.

\section{Acknowledgments}

We thank Najat Bay and Jeanine Spierings for their contribution to the data collection.

\section{References}

Albion, P. R. \& Ertmer, P. A. (2002). Beyond the foundations: The role of vision and belief in teachers' preparation for integration of technology. TechTrends, 46(5), 34-38. http://doi.org/10.1007/BF02818306

Allen, J. D. (2005). Grades as Valid Measures of Academic Achievement of Classroom Learning. The Clearing House: A Journal of Educational Strategies, Issues and Ideas, 78(5), 218-223. http://doi.org/10.3200/TCHS.78.5.218-223

Altbach, P. G., Reisberg, L. \& Rumbley, L. E. (2009). Trends in Global Higher Education: Tracking an Academic 
Revolution. A Report Prepared for the UNESCO 2009 World Conference on Higher Education. UNESCO.

Ashton, P. T. \& Webb, R. B. (1986). Making a Difference: Teachers' Sense of Efficacy and Student Achievement. New York: Longman Group United Kingdom.

Biesta, G. J. J. (2010). Good Education in an Age of Measurement: Ethics, Politics, Democracy. Boulder, Colorado: Paradigm Publishers.

Biesta, G. J. J. (2014). The Beautiful Risk of Education. Boulder: Paradigm Publishers. https://doi.org/10.4324/9781315635866

Bos, W. \& Schwippert, K. (2003). The Use and Abuse of International Comparative Research on Student Achievement. European Educational Research Journal, 2(4). https://doi.org/10.2304/eerj.2003.2.4.5

Bradshaw, C. (2013). Influences from the School. In J. Hattie \& E. M. Anderman (eds.), International Guide to Student Achievement, 111-113. New York: Routledge.

Brophy, J. (1986). Teacher influences on student achievement. American Psychologist, 41(10), 1069-1077. http://doi.org/10.1037/0003-066X.41.10.1069

Buehl, M. M. \& Beck, J. S. (2014). The Relationship between Teachers' Beliefs and Teachers' Practices. In H. Fives \& M. G. Gill (Eds.), International Handbook of Research on Teachers' Beliefs, 249-265. New York: Routledge.

Campbell, J. L., Quincy, C., Osserman, J. \& Pedersen, O. K. (2013). Coding In-depth Semistructured Interviews Problems of Unitization and Intercoder Reliability and Agreement. Sociological Methods \& Research, 1-27. http://doi.org/10.1177/0049124113500475

Cedefop. (2010). Initial vocational education and training (IVET) in Europe: Review.

Charmaz, K. (2014). Constructing Grounded Theory (Second Edition edition). Thousand Oaks, CA: SAGE Publications Ltd.

Darling-Hammond, L. (1999). Teacher quality and student achievement: A review of state policy evidence. Center for the Study of Teaching and Policy, University of Washington Seattle, WA. https://doi.org/10.14507/epaa.v8n1.2000

Dinham, S. (2005). Principal leadership for outstanding educational outcomes. Journal of Educational Administration, 43(4), 338-356. http://doi.org/10.1108/09578230510605405

Durkheim, E. (2014). The Rules of Sociological Method: And Selected Texts on Sociology and its Method. Simon and Schuster.

European Commission. (2012). Rethinking Education: Investing in skills for better socio-economic outcomes (Communication from the Commission to the European Parliament, the Council, the European Economic and Social Committee and the Committee of the Regions No. COM(2012) 669 final). Strasbourg.

European Report on the Quality of School Education. (2000). European Report on the Quality of School Education: Sixteen Quality Indicators. Luxembourg: Office for Official Publications of the European Communities.

Fives, H. \& Gill, M. G. (2014). International Handbook of Research on Teachers'Beliefs. New York: Routledge. https://doi.org/10.4324/9780203108437

Fives, H., Lacatena, N. \& Gerard, L. (2014). Teachers' Beliefs about Teaching (and Learning). In H. Fives \& M. G. Gill (Eds.), International Handbook of Research on Teachers' Beliefs, 249-265. New York: Routledge. https://doi.org/10.4324/9780203108437

Greaney, V. \& Kellaghan, T. (2008). Assessing National Achievement Levels in Education, 1, Washington, DC: The International Bank for Reconstruction and Development / The World Bank.

Guskey, T. R. (2007). Multiple Sources of Evidence: An Analysis of Stakeholders' Perceptions of Various Indicators of Student Learning. Educational Measurement: Issues and Practice, 26(1), 19-27. http://doi.org/10.1111/j.1745-3992.2007.00085.x

Guskey, T. R. (2013). Defining Student Achievement. In J. Hattie \& E. M. Anderman (Eds.), International Guide to Student Achievement, 3-6. New York: Routledge.

Haines, T. R. \& Mueller, C. E. (2013). Academic Achievement: An Adolescent Perspective. In J. Hattie \& E. M. Anderman (Eds.), International Guide to Student Achievement, 10-12. New York: Routledge.

Hammerness, K. (1999). Visions of Delight, Visions of Doubt: The Relationship Between Emotion and Cognition in Teachers' Vision. Presented at the Paper presented at the Annual Meeting of the American Educational Research Association, Montreal: Canada. 
Hammerness, K. \& Shulman, L. (2006). Seeing Through Teachers' Eyes: Professional Ideals and Classroom Practice. New York: Teachers College Pr.

Handal, B. \& Herrington, A. (2003). Mathematics teachers' beliefs and curriculum reform. Mathematics Education Research Journal, 15(1), 59-69. http://doi.org/10.1007/BF03217369

Hanushek, E. A. (1986). The Economics of Schooling: Production and Efficiency in Public Schools. Journal of Economic Literature, 24(3), 1141-77.

Hanushek, E. A. \& Raymond, M. E. (2004). The effect of school accountability systems on the level and distribution of student achievement. Journal of the European Economic Association, 2(2-3), 406-415. https://doi.org/10.1162/154247604323068096

Harris, A. (2005). Leading from the Chalk-face: An Overview of School. Leadership, 1(1), 73-87. http://doi.org/10.1177/1742715005049352

Hattie, J. (2013). Visible Learning: A Synthesis of Over 800 Meta-Analyses Relating to Achievement (1 edition). London; New York: Routledge.

Hattie, J. \& Anderman, E. M. (Eds.). (2013). International Guide to Student Achievement. Routledge. Retrieved from http://samples.sainsburysebooks.co.uk/9781136962059_sample_833110.pdf\#page=22

Henderson, A. T. \& Mapp, K. L. (2002). A New Wave of Evidence: The Impact of School, Family, and Community Connections on Student Achievement. Annual Synthesis, 2002. Annual Synthesis. Retrieved from http://eric.ed.gov/?id=ED474521

He, Y. \& Levin, B. B. (2008). Match or Mismatch? How Congruent Are the Beliefs of Teacher Candidates, Cooperating Teachers, and University-Based Teacher Educators? Teacher Education Quarterly, 35(4), 37-55.

Hursh, D. (2005). Neo-liberalism, Markets and Accountability: transforming education and undermining democracy in the United States and England. Policy Futures in Education, 1(3), 3-15. http://doi.org/http://dx.doi.org/10.2304/pfie.2005.3.1.6

Inspanningen voor Studiesucces. (2011). Inspanningen voor Studiesucces en Onderwijskwaliteit in Beeld: Evaluatieonderzoek Meerjarenafspraken in Het Hoger Onderwijs. Utrecht: Inspectie van het onderwijs/Ministerie van OCW.

Jessop, B. (2008). A Cultural Political Economy of Competitiveness and its Implications for Higher Education. In B. Jessop, N. Fairclough, \& R. Wodak (Eds.), Education and the Knowledge-Based Economy in Europe, 24, 13-39. Rotterdam: Sense Publishers.

Kneyber, R. \& Evers, J. (Eds.). (2013). Het alternatief: Weg met de afrekencultuur in het onderwijs! Amsterdam: Boom.

Krippendorff, K. H. (2012). Content Analysis: An Introduction to Its Methodology (Third Edition edition). Los Angeles; London: SAGE Publications, Inc.

Kuh, G. D., Kinzie, J., Buckley, J., Bridges, B. \& Hayek, J. (2006). What Matters to Student Success: A Review of the Literature. Washington: National Symposium on Postsecondary Student Success.

Kurland, H., Peretz, H. \& Hertz-Lazarowitz, R. (2010). Leadership style and organizational learning: the mediate effect of school vision. Journal of Educational Administration, 48(1), 7-30. https://doi.org/10.1108/09578231011015395

Ladd, H. F. \& Fiske, E. B. (2011). Weighted student funding in the Netherlands: A model for the U.S.? Journal of Policy Analysis and Management, 30(3), 470-498. http://doi.org/10.1002/pam.20589

Leithwood, K., Seashore Louis, K., Anderson, S. \& Wahlstrom, K. (2004). How Leadership Influences Student Learning. New York, NY.: The Wallace Foundation.

Maes. (2004). Vocational education and training in the Netherlands: Short description (No. Cedefop Panorama series; 96). Luxembourg: The European Centre for the Development of Vocational Training.

Mantz, Y. \& Bernard, L. (2004). Retention And Student Success In Higher Education. McGraw-Hill Education (UK).

Marzano, R. J. (2003). What Works in Schools: Translating Research Into Action (1st edition). Alexandria, Va: Association for Supervision \& Curriculum Development.

Marzano, R. J., Waters, T. \& McNulty, B. A. (2005). School Leadership That Works: From Research to Results. Alexandria, Va.: Aurora, Col.: Mid-continent Research for Education and Learning: Association for Supervision \& Curriculum Deve. 
Morgan, D. L. (1997). The Focus Group Guidebook (1st edition). Thousand Oaks, Calif. USA: SAGE Publications, Inc.

Muijs, D. \& Reynolds, D. (2002). Teachers' beliefs and behaviors: What really matters? Journal of Classroom Interaction.

Nespor, J. (1987). The role of beliefs in the practice of teaching. Journal of Curriculum Studies, 19(4), 317-328. http://doi.org/10.1080/0022027870190403

Nielsen, S. P. \& Visser, K. (1997). Quality debate in initial vocational education School-based quality measures at intermediate level: a Danish - Dutch comparison. Thessaloniki: European Centre for the Development of Vocational Training.

Nitko, A. J. \& Brookhart, S. M. (2010). Educational Assessment of Students (6 edition). Boston, MA: Pearson.

Norton, L., Richardson, T. E., Hartley, J., Newstead, S. \& Mayes, J. (2005). Teachers' beliefs and intentions concerning teaching in. Higher Education, 50(4), 537-571. http://doi.org/10.1007/s10734-004-6363-z

Onderwijsraad. (2013). Een smalle kijk op onderwijskwaliteit: Stand van educatief Nederland 2013 (No. 20130206/1027). Den Haag: Uitgave van de Onderwijsraad.

Pajares, M. F. (1992). Teachers' Beliefs and Educational Research: Cleaning Up a Messy Construct. Review of Educational Research, 62(3), 307-32. https://doi.org/10.3102/00346543062003307

Popping, R. (2010). Some views on agreement to be used in content analysis studies. Quality \& Quantity, 44(6), 1067-1078. http://doi.org/10.1007/s11135-009-9258-3

Powell, W. W. \& Snellman, K. (2004). The Knowledge Economy. Annual Review of Sociology, 30, 199-220. http://doi.org/http://www.jstor.org/stable/29737691

Ross, J. A. \& Gray, P. (2006). School Leadership and Student Achievement: The Mediating Effects of Teacher Beliefs. Canadian Journal of Education / Revue Canadienne de L'éducation, 29(3), 798. http://doi.org/10.2307/20054196

Sanders, W. L., Wright, S. P. \& Horn, S. P. (1997). Teacher and Classroom Context Effects on Student Achievement: Implications for Teacher Evaluation. Journal of Personnel Evaluation in Education, 11(1), 57-67. http://doi.org/10.1023/A:1007999204543

Scales, R. (2013). Examining the Sustainability of Pre-Service Teachers' Visions of Literacy Instruction in Their Practice. Professional Educator, 37(2).

Seginer, R. (2006). Parents' Educational Involvement: A Developmental Ecology Perspective. Parenting, 6(1), 1-48. http://doi.org/10.1207/s15327922par0601_1

Staub, F. C. \& Stern, E. (2002). The nature of teachers' pedagogical content beliefs matters for students' achievement gains: Quasi-experimental evidence from elementary mathematics. Journal of Educational Psychology, 94(2), 344-355. http://doi.org/10.1037/0022-0663.94.2.344

Studiesucces. (2014). Studiesucces: een nieuwe definitie [Study success: a new definition]. Utrecht: Landelijke Kamer van Verenigingen, Interstedelijk Studenten Overleg en Landelijke Studenten Vakbond.

Teddlie, C. \& Stringfield, S. (1993). Schools Make a Difference: Lessons Learned from a 10-Year Study of School Effects. Retrieved from http://eric.ed.gov/?id=ED366054

Thompson, A. G. (1984). The relationship of teachers' conceptions of mathematics and mathematics teaching to instructional practice. Educational Studies in Mathematics, 15(2), 105-127. https://doi.org/10.1007/BF00305892

Van de Werfhorst, H. G. (2014). Changing societies and four tasks of schooling: Challenges for strongly differentiated educational systems. International Review of Education. https://doi.org/10.1007/s11159-014-9410-8

Walberg, H. J. \& Paik, S. J. (2000). Effective Educational Practices. Educational Practices Series--3. Retrieved from http://eric.ed.gov/?id=ED443788

Wayne, A. J. \& Youngs, P. (2003). Teacher Characteristics and Student Achievement Gains: A Review. Review of Educational Research, 73(1), 89-122. http://doi.org/10.3102/00346543073001089

Yorke, M. (2007). Grading Student Achievement in Higher Education: Signals and Shortcomings. London: Routledge. https://doi.org/10.4324/9780203939413 